\title{
HAK ATAS KEKAYAAN INTELEKTUAL (HAKI) SEBAGAI HARTA BERSAMA PERSPEKTIF KOMPILASI HUKUM ISLAM
}

\author{
Arso \\ Purnabhakti Hakim Pengadilan Tinggi Agama Provinsi Sumatera Utara | Jalan S.M. Raja \\ Km. 8 Gg. Cipta Niaga No. 6 Kel. Timbang Deli Kec. Medan Amplas, Medan \\ arsopasumut@gmail.com
}

\begin{abstract}
This article discusses intellectual rights which intellectual rights have been recently acnowledged In indonesia. From the perspective of Islamic law intellectual rights can be considered as huqûq mâliyyah (property rights). Even though they have no concrete forms, they have moral and economic values. In the context of separation between husband and wife, intellectual rights can be considered as marital property which should be divided upon divorce. Otherwise, it will create injustice and defiance from the principle of maslahah in Islamic law. This recent development on intellectual rights should be accommodated in legal framworks that regulate muslim marrriage in Indonesia, such as Kompilasi Hukum Islam.
\end{abstract}

Keywords: Intellectial rights, marital property, Kompilasi Hukum Islam

\begin{abstract}
Abstrak: Artikel ini membahas tentang Hak atas Kekayaaan Intelektual sebagai Harta Bersama menurut Hukum Islam. Hak atas kekayaan intelektual (HAKI) merupakan hak eksklusif yang diakui oleh negara melalui peraturan perundang-undangan atas kreativitas intelektual yang bersangkutan. HAKI sebagai salah satu huqûq mâliyyah (hak kekayaan), merupakan benda tidak berwujud yang mempunyai nilai hak moral dan hak ekonomi yang berguna bagi kehidupan masyarakat dan kehidupan rumah tangga. Meskipun peraturan perundang-undangan terhadap HAKI tidak memberi ketegasan dan penjelasan tentang status HAKI sebagai harta bersama suami istri, namun melalui teori maslahat dan rasa keadilan serta merujuk Undang-Undang Perkawinan dan Kompilasi Hukum Islam, inkonstitusional HAKI dapat dikategorikan sebagai harta bersama dan masih relevan dengan pembagian hak masing-masing suami istri dengan bagian yang sama. Ketentuan pembagian harta bersama yang didasarkan KHI yang diberlakukan melalui Inpres No I tahun 199I, perlu ada penyempurnaan materi dan
\end{abstract}


perubahan instrumen hukumnya, khususnya berkaitan dengan HAKI sebagai harta bersama .

Kata Kunci: Hak Kekayaan Intelektual, harta bersama, Kompilasi Hukum Islam.

\section{Pendahuluan}

Harta bersama dalam kehidupan manusia, tidak dapat dilepaskan dengan hubungan perkawinan antara suami dan istri dalam rumah tangga. Perkawinan dirumuskan sebagai ikatan lahir batin antara seorang pria dengan seorang wanita sebagai suami istri dengan tujuan membentuk keluarga (rumah tangga) yang bahagia dan kekal berdasarkan Ketuhanan Yang Maha Esa. ${ }^{1}$ Kompilasi Hukum Islam (KHI) menyatakan bahwa perkawinan bertujuan mewujudkan kehidupan rumah tangga yang sakinah, mawaddah dan rahmah. ${ }^{2}$ Salah satu faktor penunjang untuk mendapatkan kebahagiaan rumah tangga tersebut adalah memiliki harta benda semasa dalam ikatan perkawinan. ${ }^{3}$

Benda merupakan padanan dari kata ${ }^{4}$ al-mâl dalam bahasa Arab. Benda dalam terminologi Kitab Undang-Undang Hukum Perdata (KUH Perdata) di Indonesia adalah tiap-tiap barang dan tiap-tiap hak yang dapat dikuasai manusia dan dapat dijadikan objek hukum. ${ }^{5}$ Kitab Undang-Undang Hukum Perdata (KUH Perdata) membedakan benda dalam beberapa kelompok. Pembedaan itu meliputi barang berwujud (lichamelijk zaak) dan tidak berwujud (onlichamelijk zaak), benda bergerak (roerend zaak) dan benda tidak bergerak (inroerend zaak), benda yang dapat dipakai

\footnotetext{
I Pasal I Undang-undang Nomor I Tahun 1974 tentang Perkawinan. Razali M. Yusuf, Himpunan Peraturan Perundang-Undangan dalam Lingkungan Peradilan Agama, (Jakarta: Direktorat Pembinaan Peradilan Agama Direktorat Jenderal Bimbingan Masyarakat Islam dan Penyelenggaraan Haji Depertemen Agama R.I., 2004), 100.

${ }^{2}$ Ibid., 309.

${ }^{3}$ Arso, "Penerapan Hukum Harta Bersama Berdasarkan Kompilasi Hukum Islam dan Pengaruhnya terhadap Pemenuhan Rasa Keadilan di Pengadilan Agama Se-Sumatera Utara" (Tesis--Program Pascasarjana Institut Agama Islam Negeri Sumatera Utara, 200 I), I.

${ }^{4}$ Kata al-mâl dirumuskan sebagai berikut: kullu mâ yumkinu khiyâratuhu wa ikhrâjuhu wa yuntafa'u bihi âdatan, Wahbah Zuhailly, al-Fiqh al-Islâmy wa Adillatuhu, (Damaskus: Dâr al-Fikri, I 409 H/I 989 M), juz IV, 40.

${ }^{5}$ Pasal 499 KUH Perdata.
} 
habis dan yang tidak dipakai habis, barang yang sekarang ada dan di kemudian hari akan ada, barang yang dapat dibagi dan yang tidak dapat dibagi. Demikian juga dibedakan adanya barang dalam perdagangan dan di luar perdagangan. Tidak kalah pentingnya dari sisi faktor kebutuhan perlunya membedakan benda, antara benda yang terdaftar dengan benda yang tidak terdaftar. ${ }^{6}$

Berkenaan dengan pembagian benda, Pasal 91 ayat (1) Kompilasi Hukum Islam (KHI.) membagi harta bersama kepada benda berwujud (lichamelijk zaak) dan benda tidak berwujud (onlichamelijk zaak). Dalam Pasal 91 ayat (2) disebutkan bahwa harta bersama yang berwujud dapat meliputi benda tidak bergerak, benda bergerak dan surat-surat berharga. Kemudian dalam Pasal 91 ayat (3) lebih lanjut disebutkan bahwa harta bersama yang tidak berwujud dapat berupa hak maupun kewajiban.

Pembagian benda yang tidak berwujud dalam harta bersama yang disebutkan dalam Pasal 91 ayat (3), merupakan objek kajian dalam tulisan ini, sehingga yang diuraikan mengenai pembagian benda adalah benda dalam kategori hak. Salah satu dari sekian banyak hak kebendaan dalam hukum perdata adalah hak kekayaan intelektual. Hak kekayaan intelektual dapat dimiliki secara perorangan dan dapat pula dimiliki secara bersama-sama oleh dua orang atau lebih. Kepemilikan hak kekayaan intelektual secara bersama-sama oleh dua orang atau lebih berarti menjadikan hak kekayaan intelektual sebagai harta bersama di antara dua orang atau lebih. Kepemilikan secara bersama di antara dua orang atau lebih dapat dilakukan oleh yang terikat dengan tali perkawinan dan dapat pula dilakukan oleh orang yang tidak terikat dengan tali perkawinan.

Pemilikan hak kekayaan intelektual yang terjadi antara dua orang yang terikat dengan tali perkawinan disebut dengan harta bersama dalam perkawinan, yang oleh pasal 35 Undang-Undang Nomor 1 Tahun 1974 tentang Perkawinan (UUP) dirumuskan

${ }_{6}^{6}$ Mariam Darus Badruzzaman, Mencari Sistem Hukum Benda Nasional, (Bandung: Alumni, 1997), 34. 
sebagai setiap harta yang diperoleh suami istri selama dalam perkawinan. Selanjutnya dalam Pasal 87 ayat (1) Kompilasi Hukum Islam (KHI) disebutkan pengecualian dengan perolehan cara hibah dan warisan. Khusus terhadap harta yang diperoleh selama perkawinan dalam terminologi fikih klasik dikategorikan atau diklasifikasikan dengan syirkah al-abdân.

Menurut terminologi fikih Islam, syirkah al-abdân pertama kali diperkenalkan dalam perang badar oleh tiga orang sahabat Nabi yang bernama Abdullah, Sa'd dan 'Ammâr yang berkongsi untuk mendapatkan ghanimah, ${ }^{7}$ bukan dalam konteks syirkah al-abdân antara suami dan istri dalam perkawinan. Tetapi di Indonesia kemudian dipopulerkan oleh Undang-Undang Perkawinan (UUP) dengan sebutan harta bersama sesuai dengan pasal 35 ayat (1) yang menyebutkan: "Harta benda yang diperoleh selama perkawinan menjadi harta bersama". Meskipun kalau dilihat putusan pengadilan agama sebelum masa kemerdekaan yang merupakan kurun waktu sebelum lahirnya UUP juga telah dikenal istilah harta bersama $^{8}$ dengan kebhinnekaan istilah, seperti gono-gini di Jawa, Hareuta sihareukat atau hareuta syarikat di Aceh, Harta suarang di Minangkabau, guna kaya di Sunda dan druwe grabo di Bali yang secara tradisional menunjukkan masyarakat Indonesia telah mengenal substansi harta bersama, ${ }^{9}$ sehingga M. Yahya Harahap menyebutkan bahwa selain harta bersama dilembagakan atas dasar syirkah al-abdân juga disebutkan bahwa harta bersama dalam perkawinan tersebut terbentuk didasarkan atas teori ' $u r f .{ }^{10}$

\footnotetext{
${ }^{7}$ Sulaiman ibn al-Asyas Abu Dawud al-Sajistani, Sunan Abû Dâmud, (Damaskus: Dar al-Fikr, t.t.), juz III, 256.

8 Putusan Raad Agama Keraksaan Nomor 23/1907. Departemen Agama, Himpunan Putusan/Penetapan Pengadilan Agama, (Jakarta: Proyek Pembinaan Badan Peradilan Agama Departemen Agama, 1976), 199.

9 Mengenai harta bersama di Aceh dapat dilihat lebih lanjut dalam penelitian Ismuha yang telah dipublikasikan. Lihat: Ismuha, Pencaharian Bersama Suami Istri di Indonesia: Adat Gono-Gini Ditinjau dari Sudut Hukum Islam, (Jakarta: Bulan Bintang, 1978), 43.

10 M. Yahya Harahap, Kedudukan Kewenangan dan Acara Peradilan Agama Undang-Undang No. 7 Tahun 1989, (Jakarta: Kartini, 1990), 297.
} 
Penyebutan harta bersama sebagai terminologi harta yang diperoleh selama perkawinan terasa terlalu global dan bersifat umum, sehingga Pasal $91 \mathrm{KHI}$ lebih merinci objek yang termasuk harta bersama. Rincian ini muncul seiring dengan perkembangan ilmu pengetahuan dan teknologi yang memasukkan hak dan kewajiban sebagai bagian benda tak berwujud ${ }^{11}$ ke dalam harta bersama. Selanjutnya Hak Atas Kekayaan Intelektual (HAKI) dimasukkan ke dalam hak sebagai bagian dari benda tidak berwujud $^{12}$ yang bersumber dari hasil kerja otak. ${ }^{13}$

Hak Atas Kekayaan Intelektual (HAKI) oleh Imam Syahputra disebutkan sebagai hak atas kekayaan yang timbul karena atau lahir dari intelektualitas manusia di bidang teknologi, atau bidang ilmu pengetahuan, seni dan sastra yang dihasilkan oleh manusia melalui kemampuan intelektualitasnya, yakni melalui daya cipta, rasa dan karsanya. ${ }^{14}$ Termasuk salah satu dari HAKI adalah hak cipta, yakni hak eksklusif bagi pencipta atau penerima hak untuk mengumumkan atau memperbanyak ciptaannya atau memberi izin untuk itu dengan tidak mengurangi pembatasan-pembatasan menurut peraturan perundang-undangan yang berlaku, sebagaimana dalam Undang-Undang Nomor 19 Tahun 2002 tentang Hak Cipta (UUHC) pada Bab I Pasal 1, huruf a.

Perkembangan ilmu dan teknologi yang dibarengi dengan diratifikasinya GATT (General Agreement on Tariffs and Trade) dan TRIPS (Trade-Related Aspects of Intellectual Property Rights) ${ }^{15}$ sebagaimana tersebut dalam Undang-Undang Nomor 7 Tahun 1994 berdampak meluasnya macam-macam hak yang tergolong dalam HAKI dilindungi oleh peraturan perundang-undangan di

\footnotetext{
I Pembagian benda kepada benda berwujud dan benda tidak berwujud dijumpai dalam Pasal 507 KUH. Perdata. Departemen Kehakiman, KUHP, (Djakarta: Daja Upaja, t.t.), 146.

${ }^{12}$ OK. Saidin, Aspek Hukum Hak Atas Kekayaan Intelektual (Intellectual Property Rights), (Jakarta: RajaGrafindo Persada, 2004), 12.

13 Ibid., 9.

${ }^{14}$ Iman Sjahputra, Hak Atas Kekayaan Intelektual, (Jakarta: Harvarindo, 2007), v.

${ }^{15}$ Dalam sidang di Puntadel Este, Uruguay, tahun 1986. Lihat: Mahkamah Agung Rl, Gatt, Trips, dan Hak Atas Kekayaan Itelektual (HAKI), (Jakarta: Mahkamah Agung RI, 1996), 4.
} 
Indonesia. ${ }^{16}$ Perlindungan terhadap HAKI sebagai hak kebendaan berakibat pemegang hak atas HAKI dapat menikmati hasil ciptaan atau invensinya.

Penempatan HAKI ke dalam benda tidak berwujud yang diklasifikasikan sebagai harta bersama sebagaimana dimaksud dalam Pasal 91 ayat (1) dan (3) KHI berdampak pada pasangan pemegang hak atas HAKI tersebut juga berhak atas HAKI yang dimiliki pasangannya. Meski secara kasat mata tidak terlihat hubungan kerja sama antara suami atau istri pemegang hak atas HAKI, tetapi karena konsep awal harta bersama bermula dari konsep syirkah al-abdân, maka keterlibatan langsung dalam menghasilkan sebuah ciptaan atau invensi bukan sebagai syarat sahnya perikatan syirkah al-abdân yang akan melahirkan harta bersama. ${ }^{17}$

Berkenaan dengan itu, konsep harta bersama yang disimpulkan dalam "diperoleh dalam perkawinan" merupakan konsep yang terasa kabur dan tidak jelas, karena hak atas HAKI tidak lahir serta-merta setelah adanya invensi, tetapi hak tersebut lahir pada saat didaftar pada Ditjen Hak Kekayaan Intelektual ${ }^{18}$ Departemen Hukum dan Hak Asasi Manusia yang memakan waktu dan biaya. Selain dari itu, berakhirnya hak atas HAKI yang menghasilkan properti tidak berhenti dengan putusnya perkawinan, tetapi masih tetap berlangsung sampai kadaluwarsanya sertifikat HAKI yang dipegang oleh inventor.

Berdiri di atas kekaburan konsep harta bersama dengan objek HAKI, Pasal 96 ayat (1) KHI menyebutkan bahwa apabila terjadi cerai mati, maka separuh harta bersama menjadi hak pasangan yang hidup lebih lama, sedangkan dalam Pasal 97 dijelaskan lebih lanjut

\footnotetext{
${ }^{16}$ Saidin, Aspek Hukum, 13-14.

17 Muhammad ibn Badr al-Dîn, Ashar al-Muhtasharût fi al-Fiqh 'alâ Mazhhab Imâm Ahmad ibn Hanbal, (Beirut: Dar al-Basya'ir al-Islâmiyah, 1416 H.), 184.

18 Pasal I angka 10 Undang-undang Nomor 14 Tahun 200 I Tentang Paten. Depertemen Hukum dan Hak Asasi Manusia Republik Indonesia, Kompilasi Undang-undang Republik Indonesia di Bidang Hak Kekayaan Intelektual, (Tanggerang: Direktorat Jenderal Hak Kekayaan Intelektual Depertemen Hukum dan Hak Asasi Indonesia, 2007), 103.
} 
bahwa janda atau duda cerai hidup masing-masing berhak seperdua dari harta bersama sepanjang tidak ditentukan lain dalam perjanjian perkawinan. Dengan demikian jelas bahwa KHI membagi dua dengan bagian yang sama terhadap harta yang diperoleh selama perkawinan berlangsung apabila terjadi perceraian, baik dalam hal ini cerai hidup maupun cerai mati.

Berdasarkan apa yang telah diuraikan di atas, maka ada masalah harta bersama yang objeknya HAKI. Untuk itu perlu kajian sejauh mana status kepemilikan HAKI yang diperoleh sebelum terjadinya ikatan perkawinan atau pemilik HAKI meninggal dunia dalam ikatan perkawinan sedangkan masa kepemilikan HAKI belum habis jangka waktunya yang ditentukan dalam sertifikat. Demikian pula dalam hal pembagian harta bersama yang objeknya HAKI bilamana pasangan suami istri terjadi perceraian. Tulisan ini merupakan kajian yang penting tentang pembagian harta bersama yang objeknya adalah HAKI dengan beberapa alasan; Pertama, tidak ada kejelasan dalam peraturan dan perundang-undangan yang mengatur tentang berbagai jenis HAKI sebagai harta bersama. Kedua, dalam pembagian sengketa bersama sering terjadi rasa ketidakadilan oleh pihak yang bersengketa. Ketiga, masih terjadi kesalahpahaman di tengah masyarakat tentang HAKI sebagai harta bersama.

\section{Konsep Hak Atas Kekayaan Intelektual dan Harta Bersama}

Perbedaan istilah tentang hak kekayaan intelektual yang diambil dari terjemahan dalam kepustakaan hukum 'Anglo Saxon' yang dikenal dengan sebutan Intellectual Property Rights sebagaimana dikemukakan terdahulu, maka singkatannya berbedabeda, ada yang menyebutkan HAKI, ada yang menyebut HaKI, dan ada pula yang HKI. ${ }^{19}$ Kesemuanya itu adalah untuk menyebutkan tentang Hak Kekayaan Intelektual.

Hak atas kekayaan intelektual (intellectual property rights) adalah serangkaian hak dan kepentingan yang sah yang terkait

${ }^{19}$ Ibid., II. 
dengan "produk" yang dapat dilaksanakan. Sedangkan pengertian kekayaan intelektual itu sendiri adalah produk tidak berwujud (intangible products) dari hasil aktivitas intelektual manusia. ${ }^{20}$ Hakikat HAKI adalah adanya suatu ciptaan tertentu atau kreasi (creation). Kreasi ini mungkin dalam bidang kesenian (art), atau dalam bidang industri ataupun bidang ilmu pengetahuan atau kombinasi antara ketiganya. ${ }^{21}$

Mengenai bentuk harta, dalam Pasal 91 Kompilasi Hukum Islam menjelaskan tentang bentuk-bentuk harta bersama, yaitu bahwa harta bersama dapat berupa benda berwujud atau tidak berwujud berupa hak maupun kewajiban, benda tidak bergerak dan benda bergerak berupa surat-surat berharga dan sebagainya. Menurut Ahmad Rofiq, aturan dalam Pasal 91 Kompilasi Hukum Islam tersebut menunjukkan adanya nuansa modern, seperti suratsurat berharga (polis, bilyet giro, saham dan lain-lain).22

Penerapan mengenai prinsip-prinsip terbentuknya harta bersama dan pembagiannya jika terjadi perceraian adalah limitatif, sepanjang tidak ditentukan lain oleh suami istri. Pembagian harta bersama dapat didekati dengan beberapa teori sebagai berikut:

1. Teori keadilan.

Keadilan menurut Tan Kamelo, terbagi tiga macam, yakni keadilan theokratik, keadilan alami dan keadilan positivis (keadilan berdasarkan undang-undang). ${ }^{23}$

Ketentuan pembagian harta bersama yang mengeneralisir seluruh keadaan pasangan suami istri semula dipandang adil, karena pada dasarnya bermaksud melindungi atau berpihak kepada istri. Namun dalam perkembangannya, dengan kemajuan zaman, istri terkadang telah mengambil fungsi sebagai kepala keluarga yang membiayai kebutuhan rumah tangga, maka porsi pembagian harta bersama, setengah untuk suami dan setengah

\footnotetext{
${ }^{20}$ Imam Sjahputra, Hak Atas Kekayaan Intelektual, I.

2'Senosa Sembiring, Prosedur dan Tata Cara Memperoleh Hak Kekayaan Intelektual di Bidang Hak Cipta Paten dan Merek, (Bandung: Yrama Widya, 2002), 14.

22 Ahmad Rofiq, Hukum Islam di Indonesia, (Jakarta: RajaGrafindo Persada, 2000), 205.

${ }^{23}$ Hasil dialog dengan Promotor pada tangal 10 September 2016.
} 
untuk istri dalam kasus ini dipandang tidak proporsional. Bahkan di beberapa daerah di Indonesia ada pihak suami yang tidak mau berpartisipasi dalam membangun ekonomi rumah tangga. Oleh karena itu, perlu adanya pertimbangan khusus tentang partisipasi pihak suami dalam mewujudkan harta bersama keluarga, sehingga bagian yang menetapkan setengah dari harta bersama untuk istri dan untuk suami perlu dilenturkan lagi sebagaimana yang diharapkan oleh Pasal 229 Kompilasi Hukum Islam. ${ }^{24}$ Maka teori keadilan proporsional dapat dipertimbangkan pada ketentuan yang mengatur tentang pembagian harta bersama untuk memenuhi rasa keadilan.

Demikian juga halnya terkait dengan pembagian harta bersama yang objeknya atas harta berupa HAKI. Pemegang HAKI telah menumpahkan melalui kekuatan intelektualnya dalam menemukan invesinya dan memperoleh status legalitas haknya sebagai pemegang HAKI yang berbeda jauh dengan aktivitas untuk memperoleh harta bersama yang objeknya non HAKI. Oleh karena itu perlu dipertimbangkan dan analisis secara mendalam untuk mencapai rasa keadilan dalam menentukan pembagian harta bersama yang objeknya HAKI.

2) Teori Maslahat.

Menurut As-Syatibi dalam al-I'tishâm mengemukakan, yang dimaksud dengan maslahat itu adalah maslahat yang tidak ditunjukkan oleh dalil khusus, yang membenarkan atau membatalkan sejalan dengan tindakan syara', artinya pada maslahat tadi ada jenis yang dibenarkan oleh syara' dalam kasus lain tanpa dalil tertentu. ${ }^{25}$

Menurut 'Izzu ad-Din ibn Abdus-Salam, mashlahah dan mafsadah sering dimaksudkan dengan baik dan buruk, manfaat dan mudharat, bagus dan jelek, bermanfaat dan bagus, sebab semua maslahat itu baik, sedangkan mafsadah itu semuanya buruk,

\footnotetext{
${ }^{24}$ Abdul Manan, Aneka Masalah Hukum Perdata Islam di Indonesia, Jakarta: Kencana Prenada Media Group, 2006), 120.

${ }^{25}$ As-Syatibi, al-l'tishâm (Beirut: Daru al-ma'rifat, tt), juz II, I I 5.
} 
membahayakan dan tidak baik untuk manusia. ${ }^{26}$ Dalam al-Qur'an, kata al-hasanât (kebaikan) sering dipergunakan untuk pengertian almashâlih (kebaikan), dan kata as-sayyiât (keburukan) dipergunakan untuk pengertian al-mafâsid (kerusakan-kerusakan). Mashlahah ada empat macam yaitu, kelezatan, sebab-sebabnya atau sarananya, kesenangan dan sebab-sebabnya atau sarananya. Sedangkan mafsadah juga ada empat macam, yaitu: rasa sakit atau tidak enak, penyebabnya atau hal-hal yang menyebabkannya, rasa sedih dan penyebabnya atau hal-hal yang menyebabkannya.

Pengertian maslahat dalam konsepsi istilah dapat ditentukan pada kajian para ushûliyyîn (para ahli ushul fikih) ketika membahas munâsib (suatu istilah yang berkaitan dengan masalah 'illat atau kausalitas hukum) dan pada saat membicarakan maslahat sebagai dalil hukum. Menurut al-Khawarizmi, yang dimaksud dengan maslahat adalah memelihara tujuan hukum Islam dengan menolak bencana atau kerusakan yang meragukan dari makhluk manusia. Sebagaimana diketahui tujuan hukum Islam adalah untuk memelihara agama, akhlak, jiwa, harta dan keturunan. Dengan demikian setiap aturan hukum yang dimaksudkan untuk memelihara kelima tujuan syara' tersebut, dengan menghindarkan dari hal-hal yang dapat merusak atau membahayakan disebut "mashlahah". Dari pengertian ini dapat diketahui bahwa sesuatu yang disebut mashlahah, barometernya adalah hukum Islam, bukan akal.

Al-Ghazali27 menjelaskan bahwa menurut asalnya mashlahah itu berarti sesuatu yang mendatangkan manfaat atau keuntungan dan menjauhkan mudharat (kerusakan), yang pada hakikatnya adalah memelihara tujuan syara' dalam menetapkan hukum. Sedangkan menurut Zakiy ad Dien Sya'ban, yang dimaksud dengan mashlahah adalah sesuatu yang ditetapkan hukum padanya sehingga dapat ditarik manfaat dari makhluk, dalam hal ini tidak ada dalil tertentu yang menunjukkannya, baik yang membenarkan

${ }^{26}$ Ar-Razi, al-Mahshûl, (Beirut: Dar al-Kutub al Ilmiyah, 1988), juz II, 319.

${ }^{27}$ Al-Ghazali, al-Mustasyfâ min 'Ilm al-Ushûl, (Beirut: Dar al Fikr, tt, Juz I), 286. 
maupun yang membatalkannya. ${ }^{28}$ Jadi, apa yang disampaikan alGhazali maupun disampaikan oleh Zakiy ad-Dien Sya'ban, berbeda redaksionalnya, tetapi intinya sama yaitu mashlahah adalah sesuatu yang tidak ditunjukkan oleh dalil tertentu yang membenarkan atau yang membatalkannya, mashlahah itu adalah sejalan dengan tindakan syara' dan tujuan hukum syara' yaitu memelihara agama, jiwa, akal, harta benda dan keturunan atau kehormatan.

Dalam menyelesaikan kasus yang belum pernah ditemukan sebelumnya seperti harta bersama yang objeknya HAKI, teori maslahat ini dapat dijadikan sebagai pemberi solusi dalam menetapkan hukum terhadap kasus harta bersama. Penerapan teori maslahat tidak hanya terbatas kepada menentukan besaran ukuran bagian yang harus diterima suami dan istri, tetapi juga dalam menentukan konsep mengenai harta bersama, sehingga menetapkan hukum yang didasarkan kepada maslahat bagi kedua belah pihak akan menimbulkan kedamaian dan terciptanya rasa keadilan hukum. Selain untuk menetapkan hukum terhadap harta bersama berdasarkan maslahat. Teori mashlahat juga dapat dijadikan sebagai dasar untuk menetapkan pilihan tentang teori apa yang dipakai dalam membagi harta bersama suami istri. Sebagai contoh, dalam menerapkan teori hudûd Syahrur, dalam pembagian harta bersama, apakah memakai teori al-had al-a'lâ atau teori al-had al-adnâ.

\section{HAKI sebagai Harta Bersama Suami Istri Perspektif UU No. 1 Tahun 1974 dan KHI}

Sri Soedewi, membedakan harta (benda) menjadi beberapa macam, yaitu: a. Barang-barang (harta) yang berwujud dan barangbarang (harta) yang tak berwujud; b. Barang-barang (harta) yang bergerak dan barang-barang (harta) yang tak bergerak; c. Barangbarang (harta) yang dapat dipakai habis dan barang-barang (harta)

${ }^{28}$ Zakiy ad Dien Sya'ban, Ushûl al-Fiqh al-Islâmiy, (t.t.p.: Dar an-Nahdad al-Rabiyah, t.t.), I 82. Lihat juga: Wahbah al-Zuhayli, Ushûl Figh al-Islâmiy, (Beirut: Dar el Fikr, 1986), 762. Yang menyatakan bahwa Muhammad saw adalah untuk menjadi rahmat sekalian alam yang sebagian rahmat itu adalah menjamin kemaslahatan manusia. 
yang tak dapat dipakai habis; d. Barang-barang (harta) yang sudah ada dan barang-barang (harta) yang masih akan ada; e. Barangbarang (harta) yang dalam perdagangan dan barang-barang (harta) yang di luar perdagangan; $f$. Barang-barang (harta) yang dapat dibagi dan barang-barang (harta) yang tak dapat dibagi. ${ }^{29}$

Dalam konsep harta kekayaan setiap barang selalu ada pemiliknya yang disebut pemilik barang dan setiap pemilik barang mempunyai hak atas barang miliknya yang biasanya disebut hak milik. ${ }^{30}$ Dalam Pasal 499 KUH Perdata menjelaskan bahwa barang adalah tiap benda atau tiap hak yang dapat menjadi objek dari hak milik. ${ }^{31}$

Tan Kamello, mengomentari Pasal 499 KUH Perdata dengan menyatakan; apabila disimak secara cermat Pasal 499 KUH Perdata, bahwa pandangan hukum perdata Barat dengan tegas membedakan barang dan hak. Secara yuridis, terlihat bahwa hak merupakan benda tersendiri, seolah-olah terlepas dari barang. Jika dibandingkan dengan paham hukum adat, maka hal yang demikian tidak dikenal. Karakter berpikir ini menunjukkan bahwa paham Barat berpikir "abstract denken", dan hukum adat berpikir "conkreet denken". Hak yang merupakan bagian dari kebendaan adalah suatu barang bergerak yang tidak berwujud (onlichamelijk roerend zaak). Oleh karena itu dalam paham KUH Perdata, harta kekayaan seorang subjek hukum meliputi barang berwujud dan hak. ${ }^{32}$

Kemudian beliau menyimpulkan bahwa dalam perkembangannya, hak yang dimaksudkan adalah termasuk semua hak kekayaan intelektual yang diatur dalam perundang-undangan tersendiri. Dalam KUH Perdata Pasal 570 disebutkan bahwa hak milik adalah hak untuk menikmati suatu benda dengan sepenuhnya dan untuk menguasai benda itu dengan sebebas-

\footnotetext{
${ }^{29}$ Sri Soedewi Masjchoen Sofwan, Hukum Perdata: Hukum Benda, (Yogyakarta: Liberty, 1974$), 19$. 30 lbid., 2.

3! Soedharyo Soimin, Kitab Undang-Undang Hukum Perdata (KUH Per), (Jakarta: Sinar Grafika, 2007), 155.

${ }^{32}$ Tan Kamello, Hukum Perdata, Hukum Benda dan Perkembangannya, (Medan: Fakultas Hukum USU, 2016), 28.
} 
bebasnya, asal tak dipergunakan bertentangan dengan undangundang atau peraturan umum yang diadakan oleh kekuasaan yang mempunyai wewenang untuk itu dan asal tidak menimbulkan gangguan terhadap hak-hak orang lain; kesemuanya itu dengan tak mengurangi kemungkinan adanya pencabutan hak itu untuk kepentingan umum, dengan pembayaran pengganti kerugian yang layak dan menurut ketentuan undang-undang. ${ }^{33}$

Oleh para ahli hukum, HAKI termasuk dalam kategori benda tidak berwujud, berupa hak yang memiliki nilai moral, praktis dan ekonomi. ${ }^{34}$ Berdasarkan apa yang dikemukakan tersebut HAKI menjadi suatu hak yang memiliki nilai moral, maksudnya merupakan hak yang melekat secara abadi pada diri pemegang HAKI dalam hal hak cipta maka melekat pada diri pencipta. Secara otomatis pemegang HAKI berhak untuk menguasai benda itu dengan sebebas-bebasnya, asal tidak dipergunakan dengan cara melawan hukum atau bertentangan dengan peraturan perundangundangan. Demikian juga HAKI sebagai hak yang memiliki nilai ekonomi, merupakan hak eksklusif pemegang HAKI atau pencipta untuk mendapatkan manfaat ekonomi yang mendatangkan keuntungan komersial. Dengan kata lain, secara yuridis, penggunaan istilah kekayaan selalu dikaitkan dengan kepemilikan hak atas benda bergerak (moveable goods), benda tidak bergerak (immoveable goods), benda berwujud (tangible goods), ataupun yang tidak berwujud (intangible goods). Dari segi sifat dan bentuknya, Hak Kekayaan Intelektual digolongkan sebagai benda bergerak tak berwujud (intangible goods). Dan secara ekonomis, hak eksklusif yang terkandung dalam Hak Kekayaan Intelektual berfungsi untuk melegalkan pemiliknya memonopoli penggunaannya atau untuk menikmati hasil yang diberikan oleh kekayaan intelektual tersebut. Hak eksklusif juga berfungsi sebagai pengatur bagi pemiliknya

\footnotetext{
33 lbid., 168.

${ }^{34}$ Rachmadi Usman, Hukum Hak atas Kekayaan Intelektual: Perlindungan dan Dimensi Hukumnya di Indonesiah, (Bandung: Alumni, 2006), 2. Lihat juga: O.K Saidin, Aspek Hukum Hak Kekayaan Intelektual, (Jakarta: Rajawali Press, 2007), 9.
} 
untuk melarang orang lain yang secara tanpa hak menggunakan atau memperoleh manfaat ekonomis dari kekayaan intelektual tersebut, mengontrol kualitas mutu barang, menjaga agar isi suatu ciptaan tidak diubah sembarangan, dan lain-lain.

Tidak selamanya barang (harta) yang dimiliki seseorang bisa tetap menjadi miliknya. Ada kalanya memiliki keinginan untuk memberikan apa yang dimiliki kepada orang lain ataupun karena sebab lain, harta tersebut berpindah menjadi milik orang lain. Begitupun HAKI, karena ia telah disamakan dengan barang (benda) yang tidak berwujud dan bisa dimanfaatkan hak-hak ekonominya seperti kekayaan-kekayaan lainnya, maka HAKI pun bisa berpindah tangan (menjadi berpindah hak kepemilikannya) kepada orang lain. Peralihan kepemilikan HAKI bisa dilihat dari adanya beberapa bentuk pengalihan kepemilikan masing-masing bidang HAKI menurut peraturan perundang-undangan.

Adapun cara peralihan kepemilikan tersebut adalah:

a. Undang-Undang Nomor 19 Tahun 2002 tentang Hak Cipta, pasal 3 ayat 2 dan terakhir dengan Undang Undang No. 28 tahun 2014 Pasal 16 ayat 2, menyatakan secara jelas menyebutkan bahwa hak cipta dapat beralih atau dialihkan, baik seluruhnya maupun sebagian karena: 1) Pewarisan; 2) Hibah; 3) Wasiat; 4) Perjanjian tertulis; atau 5) Sebab-sebab lain yang dibenarkan oleh peraturan perundang-undangan.

Selain itu, juga dipertegas ayat (3) bahwa hak cipta yang merupakan benda bergerak tidak berwujud, yang dimiliki oleh pencipta, dapat dijadikan sebagai objek jaminan fidusia. Dengan demikian jelaslah bahwa hak cipta dapat beralih atau dialihkan sebagai warisan, wasiat setelah penciptanya meninggal dunia, menjadi milik ahli warisnya atau milik penerima wasiat, dan hak cipta tersebut tidak dapat disita, kecuali jika hak itu diperoleh secara melawan hukum.

b. Undang-Undang Nomor 15 Tahun 2001 tentang Merek, pasal 40 ayat 1 . Hak atas merek terdaftar dapat beralih atau dialihkan melalui: 1) pewarisan; 2) hibah 3) wasiat; 4) perjanjian tertulis; 
atau 5) sebab-sebab lain yang dibenarkan oleh peraturan perundang-undangan.

Ketentuan pengalihan tersebut kemudian dipertegas oleh ayat (2) sampai dengan ayat (6) yang maksudnya pengalihan wajib dimohonkan pencatatannya pada Direktorat Jenderal Hak Kekayaan Intelektual untuk dicatat dalam daftar umum merek. Permohonan pencatatan disertai dokumen yang medukungnya, sehingga dapat diumumkan dalam berita resmi merek, sebab jika tidak dimuat dalam berita resmi merek, tidak berakibat hukum pada pihak ketiga. Pencatatan dikenakan pembayaran biaya pencatatan sesuai dengan ketentuan perturan perundangundangan.

c. Undang-Undang Nomor 14 Tahun 2001 tentang Paten, pasal 66 ayat 1 disebutkan bahwa paten dapat beralih atau dialihkan melalui: 1) pewarisan; 2) hibah; 3) wasiat; 4) perjanjian tertulis; atau 5) sebab-sebab lain yang dibenarkan oleh peraturan perundang-undangan.

Ketentuan tersebut tidak serta merta atas kemauan inventor untuk mengalihkan kepemilikannya. Namun sebagaimana juga seperti hak kekayaan intelektual yang lain seperti hak cipta dan hak merek, maka hak paten juga harus melalui prosedur tertentu sebagaimana diatur dalam undang-undang. Mengenai hak sebagaimana pemakai terdahulu tidak dapat dialihkan kecuali melalui pewarisan sebagaimana disebutkan dalam pasal 67. Dari apa yang telah disebutkan itu, maka jelas bahwa peralihan hak paten sebagaimana pemakai terdahulu hanya dapat dialihkan melalui pewarisan. Hal itu dikarenakan hak sebagai pemakai terdahulu sebagaimana dimaksud dalam pasal 13 bukan merupakan hak yang bersifat eksklusif, seperti halnya paten, melainkan diberikan dalam keadaan khusus. ${ }^{35}$

Pengalihan hak paten tidak menyebabkan hak moral atas paten beralih pula, nama dan identitas inventornya tetap harus

${ }^{35}$ Usman, Hukum Hak, 238. 
dicantumkan dalam paten yang bersangkutan. Karena hak moral akan tetap mengikuti inventornya sampai kapanpun walaupun patennya sudah berakhir.

Pengalihan serupa sebagaimana tersebut di atas juga berlaku bagi jenis HAKI yang lain seperti: Hak Perlindungan Varietas Tanaman (PVT) sebagaimana dinyatakan dalam Undang-Undang Nomor 29 Tahun 2000 tentang Perlindungan Varietas Tanaman, pasal 40 ayat (1), huruf a s/d e, ayat (2), ayat (3) dan ayat (4). Demikan juga pada Hak Pemilik Rahasia Dagang tersebut pada UU No. 20 Tahun 2000 tentang "Rahasia Dagang" pasal 5 ayat (1) huruf a s/d e, ayat (2), ayat (3), ayat (4) dan ayat (5). Pengalihan Hak Desain Industri sebgaimana tersebut dalam UU No. 31 Tahun 2000 tentang Desain Industri dinyatakan pada pasal 31 ayat (1) huruf a s/d e, ayat(2), ayat (3), ayat (4) dan ayat (5). Kemudian pada HAKI jenis “Desain Tata Letak Sirkuit Terpadu pengalihannya diatur dalam pasal 23 ayat (1) huruf a s/d e, ayat (2), ayat (3(ayat (4) dan ayat (5) Undang-Undang Nomor 32 Tahun 2000 tentang Desain Tata Letak Sirkuit Terpadu.

Menyimak beberapa cara yang telah dijelaskan dalam masing masing undang-undang tersebut di atas, cara yang paling unik adalah mengenai pewarisan, karena hak yang diterima oleh ahli waris dalam kaitannya hak dari masing-masing HAKI tersebut sama seperti pemilik terdahulu. Tidak seperti cara yang lain, karena memang apa yang menjadi hak waris adalah tanggung jawab sepenuhnya dari pewaris sebagaimana tanggung jawab muwarris (orang yang memiliki HAKI).

HAKI adalah suatu hak terhadap karya-karya berbentuk immaterial yang timbul sebagai akibat dari adanya kemampuan intelektualitas dalam ilmu pengetahuan dan teknologi, di mana hak tersebut diperoleh melalui pengorbanan tenaga, waktu dan biaya serta memiliki nilai ekonomis karena dapat dinikmati hasilnya.

Abdulkadir Muhammad, berpendapat bahwa Hak Kekayaan Intelektual merupakan sumber kekayaan material bagi pemiliknya karena mempunyai nilai ekonomi. Dalam kegiatan industri dan 
perdagangan, keuntungan ekonomi tidak hanya dapat dinikmati oleh pemilik, tetapi juga oleh orang lain. ${ }^{36}$ Jelas sekali bahwa HAKI sebagai suatu hak yang dimiliki oleh orang lain atas usahanya mengeluarkan kemampuan intelektualitas, sehingga bisa memperoleh sesuatu yang baru dan memiliki nilai ekonomis ini sangat urgen untuk dikaji lebih dalam.

Ketika HAKI dimiliki seseorang, maka ketika seseorang memperbanyak karya dan melisensikan hasil kemampuan intelektualnya tersebut, akan berdampak memiliki peluang untuk mendapatkan royalti dari hasil kerja tersebut. Akan tetapi, ketika si pemilik HAKI tersebut meninggal ataupun terjadi perceraian dalam rumah tangganya, maka besar kemungkinan akan terjadinya permasalahan karena adanya nilai ekonomis dari HAKI tersebut.

Membahas mengenai HAKI sebagai harta waris, sungguh sangat menarik, sebabnya HAKI merupakan sesuatu yang abstrak, tidak terlihat (tidak berupa benda yang berwujud), ia hanyalah sebuah hak yang memiliki akibat hukum dan manfaat ekonomis yang bisa dirasakan, bukan berupa harta yang bisa dipegang maupun dinikmati secara fisik layaknya rumah, mobil dan lain sebagainya. Sama seperti pembagian HAKI sebagai harta bersama, yang menjadi harta waris adalah hak ekonomi HAKI dari adanya penggunaan hak tersebut. Hak ekonomi HAKI bisa didapat melalui adanya royalti dari kegiatan (penggunaan) HAKI.

Sedangkan dalam pola pembagian HAKI sebagai harta waris, sebagaimana konsep pembagian waris yang berupa harta material yang telah dijelaskan dalam Alquran serta telah dikonsep oleh para ahli fikih, pembagian HAKI yang berupa HAKI pun bisa diwariskan demikian.

Pembagian tersebut sebagaimana yang telah menjadi hasil analisis peneliti bahwa HAKI sama seperti harta lain yang bisa digunakan dan dinikmati, akan tetapi yang diwariskan adalah hak yang nantinya dituangkan dalam royalti. Adapun sebagai contoh

${ }^{36}$ Abdulkadir Muhammad, Kajian Hukum Ekonomi Hak Kekayaan Intelektual, (Bandung: Citra Aditya, 2007), 14. 
pembagiannya yaitu ketika ada seorang laki-laki (mayyit) memiliki 1 orang istri, 1 orang anak laki-laki, dan seorang anak perempuan. Maka pembagiannya adalah sebagai berikut:

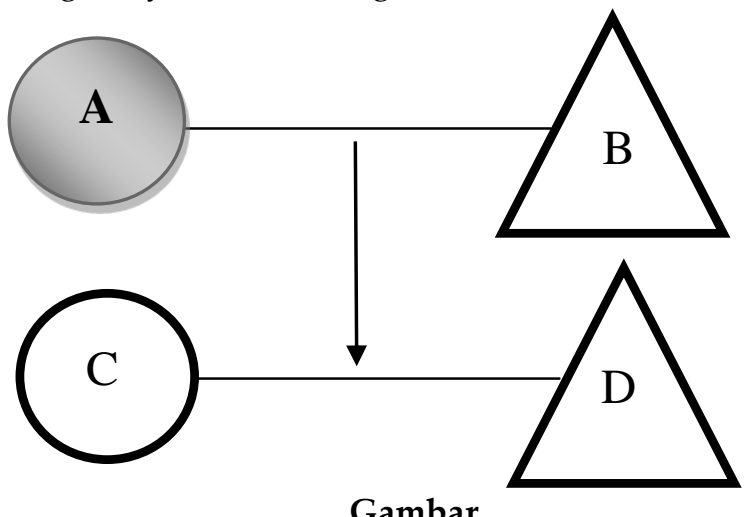

Pembagian HAKI sebagai Harta Waris

Keterangan: a) Suami (mayyit); b) Istri; c) Anak laki-laki; d) Anak perempuan

Pembagiannya adalah sebagai berikut: a. Istri mendapatkan $1 / 8$ dari kepemilikan HAKI; dan b. Anak laki-laki dan 1 anak perempuan mendapatkan ashabah bi al-ghair. Perhitungan tersebut sesuai dengan apa yang disampaikan dalam al-Qur'an surat anNisa' ayat 11 bahwa bagian anak laki-laki 2 kali bagian perempuan $(2: 1) \cdot{ }^{37}$

Adapun sebagai dasar hukum dari pembagian bagian anak laki-laki dan anak perempuan ini terdapat dalam KHI pasal 176 ayat 1 yang berbunyi: "Anak perempuan bila hanya seorang ia mendapat separuh bagian, bila dua orang atau lebih mereka bersama-sama mendapat dua pertiga bagian, dan apabila anak perempuan bersama-sama dengan anak laki-laki, maka bagian anak laki-laki adalah dua berbanding satu dengan anak perempuan".

Untuk bagian istri didasarkan pada KHI pasal 180 yang 
berbunyi: "Janda mendapat seperempat bagian bila pewaris tidak meninggalkan anak, dan bila pewaris meninggalkan anak maka janda mendapat seperdelapan". Status hukum HAKI sebagai harta warisan, tentu memenuhi ketentuan sebagaimana tersebut dalam KHI, pasal 171 huruf (g), bahwa harta warisan adalah harta bawaan ditambah bagian dari harta bersama setelah digunakan untuk keperluan pewaris selama sakit, sampai meninggalnya, biaya pengurusan jenazah (tajhîz) pembayaran hutang dan pemberian untuk kerabat.

Meskipun berbagai jenis HAKI menurut peraturan perundangundangan diatur mengenai pengalihan dengan jalan pewarisan dan lain-lain sebagaimana ketentuan dalam masing-masing undangundang dari berbagai jenis HAKI sebagaimana tersebut di atas, akan tetapi tidak mengatur HAKI sebagai harta bersama suami istri. Padahal sosok kehidupan suami istri dalam rumah tangga di negara berkembang, menunjukkan dinamika aktivitas di bidang sains dan teknologi serta kualitas intelektualitasnya dapat memperoleh harta kekayaan dalam rumah tangga dalam bentuk HAKI.

Berdasarkan salah satu prinsip HAKI adalah memiliki manfaat dan nilai ekonomi serta berguna bagi kehidupan manusia. Nilai ekonomi pada HAKI merupakan suatu bentuk kekayaan bagi pemiliknya, pencipta mendapatkan keuntungan dari kepemilikan terhadap karyanya seperti dalam bentuk pembayaran royalti terhadap pemutaran musik dan lagu hasil ciptaannya. Prinsip ekonomi, yakni hak intelektual berasal dari kegiatan kreatif suatu kemauan daya pikir manusia yang diekspresikan dalam berbagai bentuk yang akan memberikan keuntungan dan kemanfaatan kepada pemilik yang bersangkutan.

Membahas mengenai bagaimana HAKI bisa dikategorikan sebagai harta bersama (gono-gini) dalam sebuah hubungan suamiistri itu tidaklah semata-mata sebuah pemikiran sekilas, akan tetapi memiliki landasan konstitusional dan berdasarkan referensi yang ilmiyah dan konfrehensif. 
Meskipun seperangkat peraturan perundang-undangan tentang berbagai jenis Hak Atas Kekeyaan Intelektual (HAKI) secara tegas tidak menjelaskan tentang status HAKI menjadi harta bersama dalam bingkai kekayaan rumah tangga suami istri, namun dari status hukum terhadap berbagai jenis HAKI dapat beralih atau dialihkan melalui pewarisan, maka logis memenuhi kaidah dan patokan terbentuknya harta bersama sebagaimana diuraikan terdahlu, maka HAKI secara hukum dapat dikategorikan sebagai harta bersama suami istri dalam rumah tangga.

Hal ini sejalan dengan pendapat pejabat Kepala Subdit Pelayanan HAKI pada Direktoral Jenderal Hak Kekayaan Intelektual pada Departemen Hukum dan HAM RI, dalam wawancara sebagai berikut:

Pada intinya, ada tiga hal yang terpenting: Pertama, seluruh pendaftaran HAKI semuanya diproses hingga selesai untuk mendapatkan sertifikat HAKI dari Ditjend. Hak Kekayaan Intelektual di Jakarta. Kedua, dari seperangkat peraturan perundang-undangan tentang Hak Kekayaan Intelektual yang ada, tidak menemukan kejelasan tentang HAKI sebagai harta bersama suami istri dalam rumah tangga. Ketiga, HAKI sebagai hak eksklusif mempunyai ketentuan perolehannya tidak serta merta, berbeda atau tidak sama dengan perolehan harta non HAKI. Selanjutnya beliau berpendapat, meskipun peraturan perundangang-undangan tidak menjelaskan secara tegas tetang HAKI sebagai harta bersama suami istri, namun karena HAKI mempunyai nilai ekonomi dan memberi manfaat menjadi bagian dari kekayaan rumah tangga maka dapat dikategorikan sebagai harta bersama.

Demikian juga dikemukakan oleh Juraini Sulaiman, Kepala Bidang Pelayanan Hukum pada Kanwil Hukum dan HAM Provinsi Sumatera Utara, sebagai berikut:

Pada prinsipnya ada tiga hal penting: Pertama, seluruh pendaftaran HAKI diproses di Dirjend. Hak Kekayaan Intelektual Kementerian Hukum dan HAM R.I. di Jakarta. Kanwil Kementerian Hukum dan HAM Provinsi Sumatera Utara hanya menerima permohonan pendaftaran HAKI, setelah kelengkapan persyaratan dipenuhi oleh Pemohon, maka diteruskan semua berkas persyaratan ke Dirketorat 
Jenderal Kementerian Hukum dan HAM R.I di Jakarta, untuk diproses hingga penyelesaian terbitnya sertifikat HAKI dari berbagai jenis HAKI yang dimohonkan oleh Pemohon. Kedua, sepanjang pencermatan terhadap semua peraturan perundangundangan berbagai jenis HAKI, tidak diperoleh pengaturan tentang HAKI sebagai harta bersama suami istri dalam rumah tangga, walaupun adanya ketentuan peralihan Hak Kekayaan Intelektual (HKI) melalui kewarisan, hibah, wasiat, dan lain-lain, namun tidak diperoleh secara jelas kaitannya HAKI sebagai harta bersama suami istri dalam rumah tangga. Ketiga, kendatipun demikian sebagaimana dikemukakan pada butir kedua, namun beliau berpendapat, karena HAKI memilki hak ekonomi yang menjadi harta kekayaan dalam rumah tangga, maka secara hukum HAKI dapat dikategorikan sebagai harta bersama antara suami dan istri selama antara mereka terikat perkawinan yang sah. ${ }^{38}$

\section{HAKI sebagai Harta Bersama dalam Konteks KHI}

Kompilasi Hukum Islam (KHI) yang diberlakukan berdasarkan instrumen hukum INPRES No. 1 Tahun 1991, pada Pasal 91 ayat 3 menjelaskan bahwa harta bersama yang tidak berwujud dapat berupa hak maupun kewajiban. Dengan mendasarkan harta berupa hak sebagai illat dari diberlakukannya HAKI sebagai harta yang bisa diwariskan, maka berdasarkan alasan itu, memenuhi kriteria untuk dijadikannya HAKI sebagai harta bersama.

Abdullahsyah, yang sekarang menjabat Ketua Umum Majelis Ulama Indonesia Provinsi Sumatera Utara, adalah pelaku sejarah yang turut merumuskan dan mensahkan Kompilasi Hukum Islam pada Lokakarya Ulama di Jakarta pada tahun 1991. Beliau menjelaskan bahwa pada saat merumuskan materi Kompilasi Hukum Islam yang terkait dengan harta bersama tidak membahas tentang status Hak Atas Kekayaan Intelektual (HAKI) sebagai harta bersama. Selanjutnya beliau berpendapat, meskipun secara shârih atau tekstual tidak menyebutkan kedudukan hak atas kekayaan

38 Juraini Sulaiman, Kepala Bidang Pelayanan Hukum pada Kanwil Hukum dan HAM Provinsi Sumatera Utara, Wawancara, Medan. 
intelekstual (HAKI) sebagai harta bersama, namun dengan memahami pasal 91 ayat (3) KHI maka hak atas kekayaan intelektual (HAKI) dapat dikategorikan sebagai harta bersama suami istri dalam rumah tangga, karena mempunyai nilai ekonomi yang memberikan manfaat dan dinikmati dalam kehidupan suami istri dalam rumah tangga.

Taufiq, Wakil Ketua Mahkamah Agung Bidang Non-Yudisial, pada kesempatan penyampaian materi pelatihan bagi Ketua, Wakil Ketua dan Hakim se-Jawa Timur pada tahun 1999, memberikan batasan HAKI sebagai kemampuan intelektual seseorang menimbulkan ciptaan, penemuan, dan merek yang sangat berguna dalam kegiatan perusahaan, melekat suatu hak yang dapat memberikan keuntungan ekonomi kepada pemiliknya disebut hak milik intelektual. Hak intelektual merupakan bagian dari harta kekayaan immateril yang menjadi dasar untuk memperoleh keuntungan ekonomi. Harta bersama dapat berupa hak milik atas barang-barang bergerak maupun tidak bergerak, hak-hak atas barang milik orang lain, hak milik intlektual, dan harta kekayaan piutang dari suami istri atau pihak ketiga. Harta bersama meliputi: a) hasil pendapatan suami, b) hasil pendapatan istri dan c) hasil dan pendapatan dari harta pribadi suami maupun istri, merkipun harta pokoknya tidak termasuk kedalam harta bersama, dengan ketentuan kesemuanya itu diperoleh sepanjang perkawinan. ${ }^{39}$ Pada intinya beliau menyebutkan bahwa harta bersama dapat berupa hak milik intelektual (HAKI).

Pengamat hak kekayaan intelektual, Dedy Kurniadi mengatakan bahwa hak cipta yang diperoleh salah satu pasangan dalam masa perkawinan memang bisa dikategorikan sebagai harta bersama. Kedudukan karya cipta itu sama saja dengan benda bergerak lainnya seperti mobil. Pada hak cipta itu melekat hak kebendaan.

${ }^{39}$ Taufiq, Hukum Waris dan Harta Bersama, (Disampaikan pada Pelatihan Teknis Yustisial bagi Ketua, Wakil Ketua dan Hakim se-Jawa Timur dan Mataram, Tahun 1999). 
Kaedah hukum yang dirumuskan para peserta Kelompok Peradilan Agama Rapat Kerja Nasional (Rakernas) Mahkamah Agung di Makassar, awal September tahun 2015, Kelompok Peradilan Agama merumuskan bahwa royalti dari hasil karya seseorang menjadi haknya berdasarkan hak atas kekayaan intelektual. Dalam hal hak itu diperoleh dalam perkawinan yang sedang berlangsung, hak atas royalti menjadi pendapatan yang diperoleh dalam perkawinan dan karena itu menjadi harta bersama.

Selain itu, pengelolaan/pengusahaan harta bawaan yang menghasilkan tambahan atau kerugian dalam perkawinan juga dikategorikan harta bersama. Namun Dedy, mengingatkan bahwa tidak semua royalti hak cipta bisa dianggap sebagai harta bersama. Oleh karena pada hak cipta melekat hak kebendaan, maka hak cipta bisa berpindah tangan karena pewarisan, hibah, wasiat, perjanjian tertulis atau sebab-sebab lain. Jika pemegang hak cipta meninggal dunia, maka hak itu dialihkan ke ahli warisnya. Ini sejalan dengan prinsip yang dianut UU Hak Cipta No. 28 tahun 2014. Pasal 16 ayat (1) menegaskan: hak cipta dianggap sebagai benda bergerak tidak berwujud.

Komisi Fatwa Majelis Ulama Indonesia telah mengeluarkan Fatwa No. 1 Tahun 2003 tangal 14 Zulhijjah 1423 H/ 18 Januari 2003 yang menetapkan ketentuan hukum: a) Dalam hukum Islam, hak cipta dipandang sebagai salah satu huqûq mâliyyah (harta kekayaan) yang mendapat perlindungan hukum (mashun) sebagaimana mâl (kekayaan); b) Hak cipta yang mendapat perlindungan hukum Islam sebagaimana dimaksud angka 1 tersebut adalah hak cipta atas ciptaan yang tidak bertentangan hukum Islam; c) Sebagaimana mâl, hak cipta dapat dijadikan objek akad (al-ma'qûd 'alaih), baik akad mu'âwadhah (pertukaran, komersial), maupun akad tabarru'ât (non komersial) serta dapat diwakafkan dan diwarisi; d) Setiap bentuk 
pelanggaran terhadap hak cipta terutama pembajakan, merupakan kezhaliman yang hukumnya adalah haram. ${ }^{40}$

Mencermati ketentuan hukum dalam produk fatwa tersebut di atas bahwasanya hak cipta adalah huqûq mâliyyah atau harta kekayaan, maka jika dimiliki oleh seorang dengan orang lain yang terikat dalam tali perkawinan, maka secara hukum menjadi harta bersama. Musyawarah Nasional VII Majelis Ulama Indonesia Tahun 2005 menghasilkan sebuah keputusan fatwa tentang perlindungan HAKI yang di dalamnya terdapat rumusan mengenai Hak Kekayaan Intelektual, yaitu kekayaan yang timbul dari hasil olah pikir otak yang menghasilkan suatu produk atau proses yang berguna untuk manusia dan diakui oleh negara berdasarkan peraturan perundang-undangan yang berlaku. ${ }^{41}$ Kemudian dalam rumusan diktum fatwa kedua mengenai ketentuan hukum, pada point 1 sampai dengan 3, memuat sebagai berikut:

a. Dalam hukum Islam, HKI dipandang sebagai salah satu huqûq mâliyyah (hak kekayaan) yang mendapat perlindungan hukum (mashun) sebagaimana mâl (kekayaan).

b. HKI yang mendapat perlindungan hukum Islam adalah HKI yang tidak bertentangan hukum Islam (sesuatu yang tidak diharamkan).

c. HKI dapat dijadikan objek aqad (al-ma'qûd 'alaih), baik akad mu'âwadhah (pertukaran komesial) maupun 'aqd al-tabarru'ât (nonkomersial) serta dapat diwakafkan dan diwariskan.

Bertitik tolak dari status hukum HAKI sebagai huqûq mâliyyah (harta kekayaan), maka apa yang diatur dalam Kompilasi Hukum Islam tentang "Harta Kekayaan dalam Perkawinan "pada Bab XIII yang dipertegas pada pasal 91 ayat (3), bahwa harta bersama yang tidak berwujud dapat

\footnotetext{
40 Majelis Ulama Indonesia, Himpunan Fatwa Majelis Ulama Indonesia, (Jakarta: Bagian Proyek Sarana dan Prasarana, Dirjend Bimas Islam dan Penyelenggaraan Haji Departemen Agama Rl, 2003), 315-320.

4 Majelis Ulama Indonesia, Fatwa Munas VII Majelis Ulama Indonsia, (Majelis Ulama Indonesia, Tahun 2005), II.
} 
berupa hak dan kewajiban, maka dapat dipahami bahwa hak atas kekayaan intelektual (HAKI) dapat dijadikan sebagai harta bersama.

\section{Penutup}

Momentum Hak Atas Kekayaan Intelektual (HAKI) yang diperoleh atau tercipta sebelum berlangsungnya perkawinan, sedangkan yang terdaftar untuk memperoleh sertifikat sesudah terjadi perkawinan, maka secara yuridis HAKI tersebut dikategorikan sebagai harta bersama suami istri. Oleh karena itu berlaku ketentuan harta bersama sebagaimana diatur dalam Undang-Undang Nomor 1 Tahun 1974 dan Kompilasi Hukum Islam (Inpres Nomor 1 Tahun 1991), sehingga nilai ekonomi berupa royalti yang memberi manfaat sebagai kekayaan dalam rumah tangga menjadi harta bersama suami istri. Adapun Hak Atas Kekayaan Intelektual (HAKI) yang diperoleh atau tercipta dan terdaftarnya untuk memperoleh sertifikat sebelum berlangsungnya perkawinan, maka HAKI tersebut merupakan harta bawaan atau hak pribadi. Akan tetapi jika nilai ekonomi berupa royalti atas HAKI tersebut diterima atau diperoleh setelah berlangsungnya perkawinan, maka merupakan kekayaan dalam rumah tangga yang menjadi harta bersama. Demikian juga pengembangan atas HAKI yang berakibat mempunyai nilai ekonomis berupa royalti yang menjadi kekayaan dalam rumah tangga, maka hasil pengembangannya itu menjadi harta bersama suami istri. Sedangkan hak moral atas HAKI tersebut tetap melekat pada pemegang HAKI atau pencipta. Hal tersebut dinyatakan demikian, karena patokan terbentuknya suatu barang atau harta dapat dikategorikan sebagai harta bersama suami istri ditentukan oleh faktor selama antara suami dan istri terikat tali perkawinan, dikecualikan dari harta yang berasal dari "warisan" atau "hibah" yang menjadi harta pribadi yang penguasaannya di bawah tanggung jawab masing-masing, sepanjang tidak ditentukan dalam perjanjian perkawinan.

\footnotetext{
\begin{tabular}{l|l}
52 & $\begin{array}{l}\text { al-Daulah } \\
\text { Vol. 7. No. 1. April } 2017\end{array}$
\end{tabular}
} 
HAKI bersifat eksklusif merupakan karya kreativitas intelektual yang proses perolehannya melalui prosedur yang berbeda dengan perolehan harta non HAKI, maka sepatutnya didudukkan pada proporsinya. Kerja otak melalui tingkat keilmuan yang melebihi dari karya non HAKI, patut mendapat penghargaan layak dari pada aktivitas perolehan kerja seperti biasa, layaknya orang berusaha untuk memperoleh penghasilan berupa pendapatan. Oleh karena itu pembagian harta bersama berdasarkan pasal 96 dan pasal $97 \mathrm{KHI}$ dengan porsi pembagian dibagi dua dengan pembagian yang sama masih relevan dan memenuhi rasa keadilan, karena secara yuridis tekstual menyatakan pembagian harta bersama, yaitu $1 / 2$ (seperdua) untuk suami dan $1 / 2$ (seperdua) untuk istri. Walaupun kemungkinannya bisa berubah secara kasuistis berdasarkan rasa keadilan, kepatutan dan kewajaran serta memenuhi kemaslahatan sebagaimana memenuhi rasa keadilan yang dimaksud pasal $229 \mathrm{KHI}$.

Ketentuan harta bersama, KHI belum menjelaskan tentang status HAKI sebagai harta bersama secara tegas, dan pemberlakuan KHI berdasarkan instrumen hukum Inpres Nomor 1 Tahun 1991 dipandang sudah tidak relevan lagi mengikuti perkembangan hukum sebagai sumber hukum dan tata urusan perundangundangan yang berlaku di Indonesia. Untuk tercapainya kepastian hukum perlu menyempurnakan Kompilasi Hukum Islam dan mengangkatnya menjadi undang-undang untuk menjadi hukum terapan di lembaga peradilan dan kebutuhan hukum masyarakat.

\section{Daftar Pustaka}

Arso. Penerapan Hukum Harta Bersama Berdasarkan Kompilasi Hukum Islam dan Pengaruhnya terhadap Pemenuhan Rasa Keadilan di Pengadilan Agama Se-Sumatera Utara. Tesis: Program Pascasarjana Institut Agama Islam Negeri Sumatera Utara, 2001. 
Badruzzaman, Mariam Darus. Mencari Sistem Hukum Benda Nasional. Bandung: Alumni, 1997.

Departemen Agama. Himpunan Putusan/Penetapan Pengadilan

Agama. Jakarta: Proyek Pembinaan Badan Peradilan Agama

Departemen Agama, 1976.

Departemen Agama. Himpunan Putusan/Penetapan Pengadilan

Agama. Jakarta: t.p., 1976.

Departemen Hukum dan Hak Asasi Manusia Republik Indonesia.

Kompilasi Undang-Undang Republik Indonesia di Bidang Hak

Kekayaan Intelektual. Tanggerang: Direktorat Jenderal Hak

Kekayaan Intelektual Depertemen Hukum dan Hak Asasi Indonesia, 2007.

Depertemen Kehakiman. KUHP. Djakarta: Daja Upaja, t.t.

Dīn (al-), Muhammad Ibn Badr. Ashar al-Muhtasharât fi al-Fiqh 'ala Mazhab Imâm Ahmad ibn Hanbal. Beirut: Dâral-Basyâ'ir alIslâmiyah, $1416 \mathrm{H}$.

Ghazali (Al-), al-Mushthafâ min 'Ilm al-Ushûl. Beirut: Dar al-Fikr, tt. Harahap, Yahya. Kedudukan, Kewenangan dan Acara Peradilan Agama. Jakarta: PT. Garuda, 1990.

Ismuha. Pencaharian Bersama Suami Istri di Indonesia: Adat Gono-Gini

Ditinjau dari Sudut Hukum Islam. Jakarta: Bulan Bintang, 1978.

Kamello, Tan. Hukum Perdata, Hukum Benda dan Perkembangnnya. Medan: Fakultas Hukum USU, 2016.

KUH Perdata, Buku Kesatu, Bab VI. Tentang Persamaan Harta Kekayaan Menurut Undang-Undang dan Pengurusannya, Pasal 119.

Mahkamah Agung RI. Gatt, Trips dan Hak atas Kekayaan Intelektual (HAKI). Jakarta, 1998.

Majelis Ulama Indonesia. Himpunan Fatwa Majelis Ulama Indonesia. 2003. . Fatwa Munas VII Majelis Ulama Indonesia. Jakarta: Majelis Ulama Indonesia, 2005. . Fatwa Munas VII Majelis Ulama Indonsia. Majelis Ulama Indonesia, 2005. 
Manan, Abdul. Aneka Masalah Hukum Perdata Islam di Indonesia. Jakarta: Kencana Prenada Group, 2006.

Muhammad, Abdulkadir. Kajian Hukum Ekonomi Hak Kekayaan Intelktual. Bandung: Citra Aditya Bakti, 2007.

Razali, M. Yusuf. Himpunan Peraturan Perundang-Undangan dalam Lingkungan Peradilan Agama. Jakarta: Direktorat Pembinaan Peradilan Agama Direktorat Jenderal Bimbingan Masyarakat Islam dan Penyelenggaraan Haji Depertemen Agama R.I., 2004.

Razi (Ar-). al-Mahsûl. Beirut: Dar al-Kutub al Ilmiyah, 1988.

Rofiq, Ahmad. Hukum Islam di Indonesia. Jakarta: RajaGrafindo Persada, 1998.

Saidin, OK. Aspek Hukum Hak Atas Kekayaan Intelektual (Intellectual Property Rights). Jakarta: RajaGrafindo Persada, 2004.

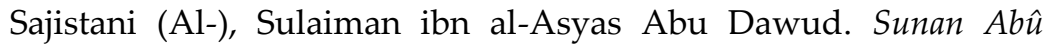
Dâwud. Damaskus: Dâr al-Fikr, t.t.

Sembiring, Sentosa. Prosedur dan Tata Cara memperoleh Hak Kekayaan Intelektual Dibidang Hak Cipta Paten dan Merek. Bandung: YRAMA WIDYA, 2002.

Sjahputra, Iman. Hak Atas Kekayaan Intelektual. Jakarta: Harvarindo, 2007.

Sofwan, Sri Soedewi Masjchoen. Hukum Perdata: Hukum Benda. Yogyakarta: Liberty, 1974.

Soimin, Soedharyo. Kitab Undang-Undang Hukum Perdata (KUH Per). Jakarta: Sinar Grafika, 2007.

Sya'ban, Zakiy ad Dien. Ushul al-Figh al-Islâmiy. t.tp.: Dar anNahdad al-Rabiyah, t.t.

Syatibi (As-). al-I'tishâm. Beirut: Dar al-Ma'rifat, t.t.

Taufiq. Hukum Waris dan Harta Bersama. Disampaikan pada Pelatihan Teknis Yustisial bagi Ketua, wakil Ketua dan Hakim se-Jawa Timur dan Mataram, tahun 1999.

Usman, Rachmadi. Hukum Hak atas Kekayaan Intelektual: Perlindungan dan Dimensi Hukumnya di Indonesiah. Bandung: Alumni, 2006. 
Utrecht, E. dan Moh. Saleh Djindang. Pengantar dalam Hukum Indonesia. Jakarta: Ichtiar Baru van Hoeve, 1989.

Zuhailly, Wahbah. Al-Figh al-Islâmiy wa 'Adillatuhu. Damaskus: Dâr al Fikr, 1428 H/ 2007 M. 